\title{
Survival strategies of chironomids (Diptera: Chironomidae) living in temporary habitats: a review
}

\author{
JAN FROUZ ${ }^{1,3}$, JoSEF MATĚNA ${ }^{2 *}$ and ARSHAD ALI ${ }^{3}$ \\ ${ }^{1}$ Institute of Soil Biology, Academy of Sciences of the Czech Republic, Na Sádkách 7, České Budějovice, CZ 37005, Czech \\ Republic \\ ${ }^{2}$ Hydrobiological Institute, Academy of Sciences of the Czech Republic, Na Sádkach 7, České Budějovice, CZ 37005, Czech \\ Republic; e-mail: matena@hbu.cas.cz \\ ${ }^{3}$ University of Florida, IFAS, Mid-Florida Research and Education Center, 2725 Binion Road, Apopka, FL32703-8504, USA
}

Key words. Insect ecology, midges, colonization, metapopulation, desiccation/frost, resistance, source-sink habitats

\begin{abstract}
Many species of chironomids undergo their immature development in habitats that rapidly change in suitability, such as rain pools, phytotelmata, freshly filled ponds or soil layers that seasonally dry out. Strategies for the utilization of these habitats can be divided into two groups: i) physiological or behavioral adaptations of larvae, which enable them to survive unsuitable conditions (in situ resistance) or ii) repeated recolonization of temporarily suitable habitats. In situ resistance, includes desiccation or frost resistance, often in combination with cocoon building and migration of larvae into the sediment. Generally, the species that use the recolonization strategy tend to be better at migration and have a higher fertility and shorter development. Recolonization may include only temporary habitats or temporary habitats and some more stable habitats as well.
\end{abstract}

\section{INTRODUCTION}

Insects of the family Chironomidae are distributed world-wide and use a variety of habitats for larval development, which in aquatic environments range from glacier brooks to sea shores and profundal zones of deep lakes and in terrestrial environments, soil, dung or fungi (Strenzke, 1950; Olivier, 1971; Hudson, 1987; Pinder, 1995; Willassen \& Thunes, 1996). Some of these habitats are only temporarily suitable for larval development. The aim of this review is to compare the life history strategies of chironomids specialized to live in temporary habitats, i.e., those that from time to time substantially and suddenly fluctuate in suitability. The suitable period is usually of short duration, close to the larval development time. Using this definition, a wide spectrum of temporarily suitable habitats for chironomids occur in nature, e.g., rain pools, phytotelmata, newly flooded ponds, soils and mosses that dry out seasonally. Some habitats that may fit into the above-mentioned definition, such as temporary streams, are not included in this review because the ecological strategies of the species inhabiting these biotopes are not sufficiently understood. Therefore, the examples given in this review are illustrative rather than exhaustive. The ecological factors that limit chironomid larvae in a temporary habitat may vary from a catastrophic environmental disturbance, such as seasonal drought or frost to more complex, and only partly explained factors such as a gradual decrease in food or other resources, or predation (Table 1). Besides the factors that affect the living conditions in temporary habitat, they may differ in the frequency and pattern of their occurrence in space and time (Williams, 1987;
McLachlan \& Ladle, 2001). In terms of occurrence some temporary habitats are spatially predictable, such as rain pools formed in small depressions in rock surfaces, which re-occur each rainy season in the same location for decades and may do so for thousands, possibly millions of years (McLachlan \& Ladle, 2001). On the other hand puddles in soft substrata may be much less stable (McLachlan \& Ladle, 2001). In addition the occurrence in time of temporary habitats may not be random, in one season they may be abundant while in another they may be rare or even absent.

Adaptations for the utilization of temporary habitats can be divided into two main groups. In situ resistance adaptations, which are a complex of physiological and behavioral adaptations that enable individuals to overcome adverse conditions in situ. The second group includes adaptations based on recolonization. These adaptations result in local populations, some of which at least partly survive and recolonize other suitable habitats when the local population there becomes extinct.

\section{IN SITU RESISTANCE}

One of the most important factors causing the extinction of chironomid larvae in temporary habitats is drought. Larvae of chironomids, both aquatic and terrestrial, have practically no ability to reduce the loss of water through their cuticle (Buck, 1965; Delettre, 1988a). In situ drought resistance consists of behavioral adaptations, which minimize water loss by transpiration and physiological adaptations that make them tolerant of water loss.

Larval migration into wetter places is a very simple behavioral adaptation (Blanchard et. al., 1987; Delettre,

\footnotetext{
* Corresponding author.
} 
TABLE 1. Some examples of the limiting factors and the life history responses of chironomids living in temporary habitats.

\begin{tabular}{|c|c|c|c|c|}
\hline Habitat & Source & Species & Response & Type of response \\
\hline Rain pools & $\begin{array}{l}\text { Hinton, 1960a } \\
\text { Jones, } 1975\end{array}$ & $\begin{array}{l}\text { Polypedilum vanderplanki } \\
\text { Paraborniella tonnoiri }\end{array}$ & $\begin{array}{c}\text { Cryptobiosis } \\
\text { Diapause, cocoon forming }\end{array}$ & in situ resistence \\
\hline Dessicating soils & $\begin{array}{l}\text { Delettre, } 1986, \\
1988 \mathrm{~b}\end{array}$ & Smittia celtica & Diapause, cocoon forming & in situ resistence \\
\hline Rain pool on peat & $\begin{array}{c}\text { Jackson \& } \\
\text { McLachlan } 1991\end{array}$ & & $\begin{array}{l}\text { Short range migration deeper into } \\
\text { the peat }\end{array}$ & in situ resistence \\
\hline Rain pools & McLachlan, 1983 & Chironomus imicola & $\begin{array}{l}\text { Recolonisation between pools, } \\
\text { metapopulation approach }\end{array}$ & recolonization \\
\hline Dessicating soils & $\begin{array}{c}\text { Frouz \& } \\
\text { Kindlmann, } 2001\end{array}$ & Smittia aterrima & $\begin{array}{c}\text { Recolonisation between suitable } \\
\text { and vulnerable and less suitable but } \\
\text { more stable habitats, source - sink } \\
\text { approach }\end{array}$ & recolonization \\
\hline Freshly filled carp ponds & Matěna, 1990 & Chironomus spp. & $\begin{array}{c}\text { Recolonisation within ponds and } \\
\text { between ponds and surrounding } \\
\text { aquatic habitats }\end{array}$ & recolonization \\
\hline
\end{tabular}

1988b). Aquatic chironomid larvae dwelling in temporary rain pools on peat can survive dry periods by migration into the deeper, wetter peat layers (Jackson \& McLachlan, 1991). Strenzke (1951) indicated that some larvae dwelling in phytotelmata may migrate to new phytotelmata to avoid desiccation. Migration into the deeper layers of soil, mud or other porous material, can significantly reduce water loss because soil air is more saturated with water than atmospheric air and soil is a barrier to water vapour diffusion (Frouz \& Matěna, in press). Building of cocoons can be another barrier, which reduces water loss by transpiration as in the Australian chironomid Paraborniella tonnoiri Freeman, which survies summer drought in cocoons in dry mud at the bottom of rain pools (Jones, 1975). Even though larvae in cocoons can survive several months in dry mud they desiccate and die quickly in air without cocoons (Jones, 1975). The cocoons are constructed from salivary gland secretion and covered with soil particles. The building of aestivating cocoons is a common feature of chironomid species dwelling in seasonal waters (Jones, 1974, 1975; Grodhaus, 1980). Species living in soils that dry out survive in situ by forming cocoons, as in Smittia celtica or tubes as in Pseudosmittia longicrus (Delettre, 1988b, Rossaro \& Delettre, 1992). Formation of cocoons in these species usually occurs in a particular larval stage, 2nd or 3rd instar (Delettre, 1975; Grodhaus, 1980). Aestivation and formation of cocoons occur even when larvae are continuously in water, indicating occurrence of an obligatory summer diapause (Grodhaus, 1980). Overwintering cocoons are formed by some chironomids inhabiting permanent water bodies, such as Endochironomus tendens Fabricius and Dicrotendipes sp. (Thienemann, 1921; Saether, 1962) and Camptochironomus tentans Fabricius (Matěna, unpublished). All these forms prefer littoral areas with macrophytes and are potentially endangered by a receding water level or frost.

Tolerance of water loss is the main physiological adaptation affecting drought resistance in chironomid larvae. Larvae of Polypedilum vanderplanki Hinton can survive almost complete desiccation. Their water content can decrease to about $3 \%$ of that of active larvae. This is called cryptobiosis during which they can survive exposure to temperatures from $-270^{\circ} \mathrm{C}$ to $+120^{\circ} \mathrm{C}$. Larvae kept in completely dry air can be resuscitated even after 18 years (Hinton, 1951, 1960a, b; Adams, 1985). Physiological mechanism of this desiccation tolerance is explained by the accumulation of trehalose, which provides protection against desiccation cell damage due to its water replacement capacity (Watanabe et al., 2003). Accumulation of trehalose in the desiccation phase is induced by changes in osmolarity in the larval body (Watanabe et al., 2003). This tolerance of desiccation is not specific to a larval instar and they may recover from desiccation up to 10 times during larval development (Hinton, 1960a). Other chironomid larvae can also survive a substantial loss of body water. Paraborniella tonnoiri can survive the loss of $72 \%$ of its water content and Chironomus dorsalis Meigen 50\% (Buck, 1965; Jones, 1975; Frouz \& Matěna, in press). Adams (1985) listed several other chironomid species, such as Polypedilum dewulfi Goethebuer, which can tolerate a considerable degree of dehydration. Futhermore, chironomids that inhabit permanent waters, both lentic and lotic, may survive a $30-50 \%$ loss of body water (Frouz \& Matěna, in press). As cocoons are not an absolute barrier against water loss, the cocoon forming larvae survive dry periods partly dehydrated (Jones, 1975; Grodhaus, 1980). Some ability to survive desiccation is recorded for several Metriocnemus species dwelling in phytotelmata (Picado, 1913; Zavřel, 1941; Strenzke, 1951). The ability of $P$. vanderplanki to survive water loss is extraordinary and there are numerous chironomid species that can survive a considerable loss of body water as larvae, and a wide range of desiccation tolerance is reported for larvae of various species of chironomids (Buck, 1965; Jones, 1975; Adams, 1985; Frouz \& Matěna, in press).

Another environmental factor that can substantially reduce populations of chironomid larvae is freezing (Jackson \& McLachlan, 1991). Chironomidae overwinter exclusively as larvae and some species form winter cocoons (Tokeshi, 1995). A reduction in body water con- 
tent is recorded for overwintering larvae (Danks, 1971), which indicates that the mechanism of frost and drought resistance may be similar. Danks (1971) concluded that freezing tolerance is quite common in many chironomid species. Butler (1982) described a 7-year life cycle for two Chironomus species in the tundra ponds in arctic Alaska, where the sediments are frozen for about 9 months of the year. This implies that these larvae must be frost tolerant. Temporary habitats determined exclusively by frost are scarce, nevertheless frost affects chironomids, particularly in shallow water in temperate zones affected by both summer drying and winter freezing (Jackson \& McLachlan, 1991).

\section{RECOLONIZATION}

Rain pools or soils and mosses that dry out seasonally are good examples of temporary habitats influenced by "catastrophic" events. The life-history strategies of chironomids inhabiting rock pools have been studied in detail in Africa (Cantrell \& McLachlan, 1982; McLachlan, 1983, 1986; McLachlan \& Ladle, 2001). The pools that last for c. 1 week are inhabited by the drought resistant $P$. vanderplanki while those that last for c. 2-3 weeks are densely inhabited by Chironomus imicola Kieffer and Chironomus pulcher Wiedeman, which are not drought resistant (Cantrell \& McLachlan, 1982; MacLachlan, 1983). These species are indigenous in rain pools. Population persistence is ensured by the colonization of new rain pools, which appear due to the high spatial variability in rainfall. This strategy results in a different evolutionary pressure on the larvae and adults. The fittest larvae are those with the shortest development time, which enables them to emerge from pools before desiccation. By contrast, the fittest adults (particularly females) are the largest, as large size is associated with both high fertility and good migration ability (McLachlan, 1983), but this requires a long larval growth period. This paradox is resolved by a shift in larval stage duration depending on population density. At low densities, corresponding with initial colonization, there is a high variability in development time, ranging from 12 to 40 days. The weight of the adults correlates positively with development time. Early emergence increases the probability of emergence before a pool dryes out but the females have a low fertility and poor migration ability. At high densities, intense competition is accompanied by high mortality (McLachlan, 1983). Dead larvae can be a valuable food source and support rapid growth of the survivors. This additional food resource results in larger adults and short development times (McLachlan, 1983). Mc Lachlan (1989) thinks that both phenotypes of larvae: giants resulting in large adults, and dwarfs, that grow and develop more slowly and are easily killed in competition with the giants, are genetically determined. Their frequency in the population is maintained by density dependent selection within an evolutionary stable strategy. Because larvae in one puddle often originate from one egg mass dead competitors in fact support the survival of their relatives. In this context the interaction between body size and development time in C. imicola described above is a special example of altruism (McLachlan \& Ladle, 2001). In conclusion, the production of offspring by a local population is optimized, depending on the desiccation risk, by variations in larval development time, adult size and larval mortality according to larval density. Nevertheless, rain pools do not occur randomly throughout a year as they are absent during the nine month dry season. Both $C$. imicola and $C$. pulcher survive this period in pools left by receding rivers. It is also speculated that some occur at low densities in more stable habitats such as rivers or lakes but except for one record of C. pulcher from a stream they have never been found in such habitats (McLachlan, 1988). Ghonaim (2002 and pers. com.) collected larvae of $C$. imicola from margins of the river Nile and some irrigation channels. Chironomus dorsalis Meigen almost exclusively inhabits temporary habitats of different types in Central Europe (Matěna \& Frouz, 2000). Records of this species from more permanent habitats are rare (Matěna \& Frouz, 2000). The life strategy of this species is poorly known, and the importance of rain pools and other habitats for the survival of this species needs further investigation. This species is not more resistant to desiccation than Chironomus riparius Meigen, a related species inhabiting permanent habitats, which can survive several days in wet mud, but cannot survive the drying out of the mud (Frouz \& Matěna, in press). The species can survive by colonizing rain pools and perhaps in sub-optimal habitats. The short development time (12-14 days at $23-25^{\circ} \mathrm{C}$; Dettinger-Klemm, 2000) may be advantageous in this regard. The shortest generation time for Chironomidae, less than 7 days at $28^{\circ} \mathrm{C}$, is recorded for Apedilum elachistius Townes living in rock pools in the Mato Grosso (Brazil) (Nolte, 1995). Experiments revealed no drought-resistance in this species. The principal mechanism permitting $A$. elachistius to colonize ephemeral habitats is apparently its short generation time. However this species seems to be a generalist and not specific to temporary habitats, inhabiting also adjacent pools and brackish waters. It tolerates a broad range of temperatures (from at least 8 to $42^{\circ} \mathrm{C}$ ), does not feed selectively and has little requirement for spatial habitat structures (Nolte, 1995). These examples indicate that a short life cycle is advantageous in temporary habitats, but even an extremely short life cycle does not automatically mean specialization for these habitats.

Unpredictable desiccation can commonly occur in the small aquatic habitats associated with living plants, phytotelmata, which range in size from small accumulations of water in leaf axils of Scirpus silvaticus to tree holes. An overview of these habitats is available in Pinder (1995). Metriocnemus martini Thienemann is a specialized midge inhabiting tree holes. These habitats vary in desiccation risk according to size. Mayer (1938) indicates that large tree holes can be almost permanent habitats but there is a risk of desiccation in small tree holes. Metriocnemus martini prefers small tree holes in the canopy, probably because of a better food supply (Kitching, 1971, 1972). These habitats are at a high risk of desiccation, but 
as eggs are laid almost continuously during the entire vegetation season, drought affected holes are quickly recolonized from larger and more stable habitats (Kitching, 1972). Moreover, M. martini has some ability to survive desiccation in the wet substrate at the bottom of tree holes (Zavřel, 1941).

Catastrophic desiccation is important also in terrestrial habitats. Some species of terrestrial chironomids are abundant in the thin layers of moss and lichen that grow on rock surfaces (Delettre, 1975, 1986, 1989). These habitats are highly sensitive to drying in summer. Larvae of some terrestrial chironomids, such as Smittia celtica Rossaro \& Delettre, can survive dry periods in cocoons (Delettre, 1988b) but not others, such as Limnophyes minimus Meigen. The latter species has, under these conditions, two generations per year. Its larvae are abundant in moss and lichen during winter when this habitat is saturated with water but disappear during early summer due to drought. In autumn the habitat is recolonized by adults emerging from more stable habitats such as various permanently wet habitats that host permanent populations (Delettre, 1986). This recolonization enables the species to persist (Ducrotoy, 1980; Delettre, 1986, 1989; 1994). A similar strategy is also observed in Smittia aterrima Meigen, which develops in bare soil or poorly vegetated patches of early fallows. This species is abundant in these habitats in winter but in summer disappears due to drought and the habitats are recolonized in autumn by individuals that developed in more desiccation resistant habitats (Frouz, 1997; Frouz \& Kindlman, 2001). The reason for the utilization of these open soil habitats is probably the abundant occurrence there of soil algae and mosses, which are a valuable food source (Frouz \& Lukešová, 1995). S. aterrima is commonly found in various habitats such as meadows or arable fields (Delettre \& Lagerlöf, 1992; Frouz, 1994). More stable habitats such as grasslands support low densities of larvae and produce a small proportion of the annual offspring. Some populations in sub-optimal habitats are supported by immigrants from optimal habitats and disappear when the optimal habitats disappear (Frouz, 1994, 1997). The combination of permanent but sub-optimal habitats and suitable and temporary habitats may ensure population persistence (Frouz \& Kindlman, 2001).

Other examples of temporary habitats are newly filled ponds and rice fields where regular drying is an integral part of fish-pond management or rice cultivation. Due to the rapid changes in environmental conditions that occur after flooding these habitats become highly suitable for colonization by some chironomid species for a short period, possibly a consequence of a complex of factors rather than a single factor (Morduchaj-Boltovskoj, 1961; Hilsenhoff, 1967; Lellák, 1969; Barthelmes, 1970; Sukop, 1974; McLachlan \& Cantrell, 1976; McLachlan \& McLachlan, 1976; McLachlan, 1977). The midges occur also in a wide range of sub-optimal habitats but at much lower population densities than in freshly filled ponds, which are intermediate between typical temporary habi- tats and fluctuations of living conditions common everywhere. These habitats are densely colonized by larvae of the genus Chironomus. Carp ponds are man-made habitats but natural habitats similar to newly flooded ponds are produced when rivers flood. In the water on flood plains, larvae of Chironomus spp. are typical early colonizers (Steinhart, 2000). Based on ecological studies, which used karyotaxonomy, Chironomus annularius Meigen, Chironomus melanescens Keyl and Chironomus piger Strenzke are thought to be specialists of newly flooded ponds (Matěna, 1990). Similarly as Chironomus tepperi Skuse in rice fields in Australia (Martin, 1974). Usually only one abundant generation develops after flooding (Matěna, 1979, 1982, 1990). Later, larvae can be found in ponds and in a wide range of other habitats but in substantially lower numbers (Matěna, 1990). The reasons for the decline in numbers of these pioneer species are probably complex and include changes in substrate (Morduchaj-Boltovskoj, 1961; Lellák, 1969; Sukop, 1974; McLachlan \& Cantrell, 1976; McLachlan \& McLachlan, 1976; McLachlan, 1977), food availability, predation or diseases (Hilsenhoff, 1967; Barthelmes, 1970). As in the case of terrestrial chironomids mentioned above, newly flooded ponds are strongly preferred for oviposition in comparison to similar ponds without fish flooded several weeks earlier (Matěna, 1990). Stevens et al. (2003) proved experimentally that chemical cues from larval populations deter oviposition by C. tepperi females searching for newly flooded habitats, where there is likely to be little larval competition. Chironomus melanescens is a typical species using newly filled fishponds in Central Europe. The abundance of Ch. melanescens in these habitats can exceed 4000 larvae per $\mathrm{m}^{2}$ (Matěna, 1990). This species is only rarely found in permanent peaty ditches, which may represent a sub-optimal habitat but potential refuge (Matěna \& Frouz, 2000). The abundance of larvae in these sub-optimal habitats is significantly lower and they are negligible in area compared to the optimal habitats (Matěna \& Frouz, 2000). The sub-optimal habitats, however, may play an important role in the long-term survival of the population. Changes in chironomid larval abundance after flooding are the subject of many ecological studies (e.g. Hilsenhoff, 1967; Barthelmes, 1970; McLachlan \& Cantrell, 1976; McLachlan \& McLachlan, 1976; McLachlan, 1977; Matěna, 1979, 1982, 1990), but the mechanisms by which new ponds are colonized and the role of optimal and sub-optimal habitats in the population dynamics is neglected.

Finally, in addition to temporary habitat specialists there are generalist species, which maintain stable populations in permanent habitats and colonize temporary habitats as described above for L. minimus or A. elachistius. Generalists are particularly important when temporary habitats are relatively long lasting (Williams, 1987).

\section{COMPARISON OF STRATEGIES}

\section{In situ resistance versus recolonization}

Generally species that are able to survive in temporary habitats in situ appear earlier then colonists and are also 
less limited by habitat duration (Williams, 1987). An extensive comparison of in situ resistance and recolonization was made on African rain pool dwellers living in the same area; $P$. vanderplanki and two species of Chironomus (C. imicola and C. pulcher) (McLachlan, 1983). In Chironomus, the larval development and life cycle are shorter, adult females migrate greater distances and lay a higher percentage of their eggs in pools other than the one they developed in and are more fecund, and unlike $P$. vanderplanki are able to produce additional egg clutches after feeding as adults (McLachlan, 1983; McLachlan \& Yonow, 1989). Larval and adult size is more variable in Chironomus than in P. vanderplanki and both larval and adult size are affected by larval density, which changes during the desiccation of the habitat. In contrast, no changes in larval density occur in $P$. vanderplanki populations during desiccation (McLachlan, 1983).

There is another comparison of in situ resistance and recolonization strategies in terrestrial chironomids dwelling in the moss and lichen layers on rock surfaces in Brittany (France). Short life cycles also occur in colonizing species of terrestrial chironomids. The colonizing species $L$. minimus has two generations per year, whereas the in situ resistant species, Smittia pratorum and Smittia celtica have only one (Delettre, 1986, 1988b). The higher number of generations per year facilitate recolonization of habitats on the rocks and in the surrounding landscape. A higher proportion of migrants are produced by recolonizing species than in situ survivors (Delettre, 1986, 1988b). Unlike in the drought resistant species, the migrants and non-migrants in recolonizing species differ in wing length (Delettre, 1988b).

In in situ resistance, the better the individual adaptation, physiological or behavioral, for survival the higher success of the whole population. Selection acts in the same way on all individuals in the population - in one direction. This may lead to uniformity within populations. In the recolonization strategy there are often several more complex adaptations, such as short life cycle, high fertility, high migration ability, habitat selectivity etc. In some cases a trade-off between particular adaptations is observed. Consequently the population is exposed to different selection pressures in time and space, which leads to high variability in populations and the coexistence of several phenotypes.

\section{Recolonization strategy - from specialists to generalists}

Fluctuations in the frequency of occurrence of suitable temporary habitats is a critical aspect of the recolonization strategy. In some cases suitable temporary habitats may be periodically rare or even absent (McLachlan, 1988; Frouz \& Kindlman, 2001). These periods constitute bottlenecks (McLachlan, 1988) and a more detailed analysis of them may be helpful in further understanding of the population dynamics of insects using temporary habitats.

As is apparent from the above examples, the use of more stable habitats is frequent among species that use temporary habitats. Some temporary habitat specialists may use several types of temporary habitat, some more durable than others. For example, the longer lasting but also temporary pools of river water left by receding rivers used by $C$. imicola and $C$. pulcher during the dry season when their usual habitat, temporary rain pools, completely disappear (McLachlan, 1988). Or species may use almost permanent habitats that are similar to temporary ones. For example, the more permanent large phytotelmata and the less permanent smaller ones, in the case of M. martini (Kitching, 1972). In other situations the differences between temporary and permanent habitats may be more pronounced, as in $S$. aterrima dominating in pioneer habitats that occur in grassland (Frouz, 1997). In these and some other species the abundance in stable habitats is often several orders of magnitude lower than in optimal, temporary habitats (McLachlan, 1988; Frouz, 1997; Matěna \& Frouz, 2000; Frouz \& Kindlman, 2001). Some authors (McLachlan, 1988; Frouz, 1997; Frouz \& Kindlman, 2001) suggest that these sub-optimal habitats are not self-sustainable and the populations there are maintained by immigration from optimal habitats, i.e. sink habitats in the sense of Pulliam (1988), Pulliam \& Danielson (1991). Here we use the term source habitat for those where production in long term average compensates for local mortality and emigration exceeds immigration and sink habitat for those where production does not compensate for local mortality and immigration exceeds emigration (Puliam, 1988; Puliam \& Danielson, 1991). This does not mean that there is no migration from sink to source; this migration is in fact necessary to maintain an evolutionary stable strategy (Morris, 1991), but the number of such migrants is in the long term less than in the opposite direction. Moreover, sink to source migrants may be important when the population in the source habitat is depleted for some reason. In this particular case the sink habitat becomes the source habitat. This also applies to the recolonization of temporary habitats by migrants from some sub-optimal permanent habitats. In the case of $S$. atterima studies indicate that populations in sub-optimal, stable habitats (grasslands) decline and even become extinct when optimal (pioneer) habitats disappear (Frouz, 1994, 1997), which indicates that they are true sink habitats. Nevertheless, even these sink populations may play a substantial role in the recolonization process (Frouz \& Kindlman, 2001). There is little information on the role of the sub-optimal habitats in recolonization even though this factor may be important in insect ecology (Frouz, 1997; Boughton, 1999; Frouz \& Kindlman, 2001).

Finally, the permanent habitats of species such as $L$. minimus may be self-sustainable and this species colonizes temporary habitats when suitable (Delettre, 1986). Similarly in other generalist species that occupy temporary habitats, where they occur commonly but are maintained by immigration from more permanent habitats (Williams, 1987). Most generalists are limited by habitat duration and as a consequence become more common when the duration of the suitable phase of the habitat is long (Williams, 1987). However some generalists, such as Apedilum elachistius, are well adapted for using tem- 
porary habitats because they have the shortest life cycles (Nolte, 1995).

As is apparent from these examples the habitats used by both temporary habitat specialists and generalists show a gradient in habitat persistence. For specialists the persistent and the temporary habitats are similar in character, whereas for generalists there is a greater difference between these habitats. Persistence of generalists in temporary habitats may be limited by their life cycle duration (Williams, 1987). However, the extremely short life cycle of the generalist, A. elachistius, indicates that other factors are important for temporary habitat specialists. The pattern of environmental stochasticity could be an important factor affecting the use of more permanent habitats. The use of more stable habitats may be advantageous when environmental conditions are highly spatiotemporarily correlated as when a seasonal drought affects a large area (Delettre, 1986; McLachlan, 1988; Frouz \& Kindlman, 2001).

ACKNOWLEDGEMENTS. This study was supported by the Grant Agency of the Czech Republic (No 526/98/P156), project MSMT-J06/98:124100001 supported by Czech Ministry of Education and projects Z6017912, K6005114 and Z6066911 supported by Academy of Sciences of the Czech Republic. The authors would like to thank Dr. Y. Delettre and one anonymous referee for their criticism and helpful comments.

\section{REFERENCES}

Adams S. 1985: Cryptobiosis in Chironomidae (Diptera) - two decades on. Antenna 8: 58-61.

Barthelmes D. 1970: Die Wirkung der Trockenlegung auf das Makrozoobenthos des Karpfenteiches. Z. Fisch. 18: 55-80.

Blanchart E., Frenot Y. \& Trehen P. 1987: Significance biologique du potentiel hydrique dans la distribution des Dipteres a larves hydrophiles. Pedobiologia 30: 333-344.

Boughton D.A. 1999: Empirical evidence for complex sourcesink dynamics within alternative stages in butterfly metapopulation. Ecology 80: 2727-2739.

Buck J.M. 1965: Hydratation and respiration in chironomid larvae. J. Insect Physiol. 11: 1503-1516.

Butler M.G. 1982: Production dynamics of some arctic Chironomus larvae. Limnol. Oceanogr. 27: 728-737.

Cantrell M.A. \& McLachlan A.J. 1982: Habitat duration and dipteran larvae in tropical rain pools. Oikos 38: 343-348.

DANKS H.V. 1971: Overwintering of some north temperate and arctic Chironomidae. Can. Entomol. 103: 1875-1910.

Delettre Y.R. 1975: Elements de la Dynamique d' une Population de Parasmittia carinata Strenzke (Diptera, Chironomidae) dans une Formation Pioniere de la Lande Armoricaine. These doctorat $3^{\circ}$ cycle, Universite de Rennes, Rennes.

Delettre Y.R. 1986: La colonisation de biotopes multiples: une alternative à la résistance in situ aux conditions mésologiques défavorables. Cas de Limnophyes minimus (Mg.), Diptère Chironomidae à larves édaphiques des landes armoricaines. Revue Ecol. Biol. Sol 23: 29-38.

Delettre Y.R. 1988a: Flux d'évaporation corporelle et resistance á la desiccation chez les larves de quelques Chironomidae terrestres (Diptera). Revue Ecol. Biol. Sol 25: 129-138.

Delettre Y.R. 1988b: Chironomid wing length, dispersal ability and habitat predictability. Holarct. Ecol. 11: 166-170.
DelettRe Y.R. 1989: Response of terrestrial chironomid communities to fire: an experimental study on heatlands in Brittany (France). In: Devai G. (ed.): Advances in Chironomidology, Proc. Xth Int. Symp. Chironomidae, Debrecen, Hungary, 1988, Part 2 Acta Biol. Debrecin Oecol. Hung. 3: 99-110.

Delettre Y.R. \& LAGerlöF J. 1992: Abundance and life history of terrestrial Chironomidae (Diptera) in four Swedish agricultural cropping systems. Pedobiologia 36: 69-78.

DelettRe Y.R. 1994: Fire disturbance of a chironomid (Diptera) community on heathlands. J. Appl. Ecol. 31: 560-570.

DetTinger-KLemm M.P.A. 2000. Influence of temperature and photoperiod on development in three species of Chironomidae (Diptera) - Chironomus dorsalis Meigen, 1818, Polypedilum uncinatum (Goethebuer, 1921) and Paralimnophyes hydrophilus (Goethebuer, 1921) - living in temporary pools. In: Hoffrichter O. (ed.): Late $20^{\text {th }}$ Century Research on Chironomidae: an Anthology from the $13^{\text {th }}$ International Symposium on Chironomidae. Shaker Verlag, Aachen, 295-308 pp.

Ducrotoy J.P. 1980: Adaptations spatio-temporelles de chironomides (Insectes: Dipteres) dans un habitat semi-permanent du massif de Paimpont. Bull. Ecol. 11: 633-645.

Frouz J. 1994: Changes in terrestrial chironomid community (Diptera: Chironomidae) during secondary succession in old fields. Pedobiologia 32: 334-343.

Frouz J. 1997: The effect of vegetation patterns on oviposition habitat preference: A driving mechanism in terrestrial chironomid (Diptera: Chironomidae) succession. Res. Popul. Ecol. 39: 207-213.

Frouz J. \& Kindluan P. 2001: The role of sink to source recolonisation in the population dynamics of insects living in unstable habitats: an example of terrestrial chironomids. Oikos 93: 50-58.

Frouz J. \& LuKEšová A. 1995: Food preference of two species of terrestrial chironomids (Diptera: Chironomidae). Dipter. Bohem. 7: 41-46.

Frouz J. \& Matěna J.: Desiccation resistance of some aquatic and terrestrial chironomids. Mem. Inst. Osw. Cruz. [in press]

Ghonam F.M. 2002: Ecological and Taxonomical Studies of Family Chironomidae (Order: Diptera) in Egypt. $\mathrm{PhD}$. Thesis Al-Azhar University, Nasr City, Cairo, $287 \mathrm{pp.}$

Grodhaus G. 1980: Aestivating Chironomid larvae associated with vernal pools. In: Murray D.A. (ed.): Chironomidae Ecology, Systematic, Cytology and Physiology. Pergamon Press, Oxford \& New York, 315-322 pp.

HILSENHOFF W.L. 1967: Ecology and population dynamic of Chironomus plumosus (Diptera: Chironomidae) in Lake Winebago, Wisconsin. Annls Entomol. Soc. Am. 60: 1183-1194.

HinTon H.E. 1951: A new chironomid from Africa, the larva of which can be dehydrated without injury. Proc. Zool. Soc. London 121: 371-380.

Hinton H.E. 1960a: Cryptobiosis in the larva of Polypedilum vanderplanki Hint. (Chironomidae). J. Insect Physiol. 5: $288-300$.

HINTON H.E. 1960b: A fly larva that tolerates dehydratation and temperature from $-270^{\circ} \mathrm{C}$ to $+120^{\circ} \mathrm{C}$. Nature 188: $336-337$.

Hudson P.L. 1987: Unusual larval habitats and life history of Chironomid (Diptera) genera. Entomol. Scand. Suppl. 29: 369-373.

JACKSON J.M. \& MCLACHLAN A.J. 1991: Rain pools on peat moorland as island habitats for midge larvae. Hydrobiologia 209: 59-65.

JONES R.E. 1974: The effect of size selective predation on the environmental variation in the distribution and abundance of a 
chironomid, Paraborniella tonnoiri Freeman. Aust. J. Zool. 22: $71-89$.

JONES R.E. 1975: Dehydratation in an Australian rockpool chironomid larva Paraborniella tonnoiri. J. Entomol. 49: 111-119

Kitching R.L. 1971: An ecological study of water filled treeholes and their position in the woodland ecosystem. J. Anim. Ecol. 40: 281-302

Kitching R.L. 1972: Population studies of the immature stages of the tree hole midge Metriocnemus martini Thienemann (Diptera: Chironomidae) J. Anim. Ecol. 41: 53-61.

LELLÁK J. 1969: The regeneration-rate of bottom fauna populations of the fish ponds after wintering or summering. Verh. Int. Verein. Limnol. 17: 560-569.

MarTin J. 1974: A review of the genus Chironomus (Diptera: Chironomidae) IX. The cytology of Chironomus tepperi Skuse. Chromosoma (Berlin) 45: 91-98.

MATĚNA J. 1979: Benthos regeneration after summer pond drying. Buletin VURH Vodnany. 1: 22-32. [in Czech, English abstr.]

MATĚNA J. 1982: Benthos development in planktonic and nursery ponds. Buletin VURH Vodnany 4: 10-15. [in Czech, English abstr.]

MATĚNA J. 1990: Succession of Chironomus Meigen species (Diptera: Chironomidae) in newly filled ponds. Int. Rev. Ges. Hydrobiol. 75: 45-57.

MatĚna J. \& Frouz J. 2000: Distribution and ecology of Chironomus Meigen species in the Czech Republic (Diptera: Chironomidae). In: Hoffrichter O. (ed.): Late $20^{\text {th }}$ Century Research on Chironomidae: an Anthology from the $13^{\text {th }}$ International Symposium on Chironomidae. Shaker Verlag, Aachen, pp. 543-548.

Mayer K. 1938: Zur Kenntnis der Buchenhöhlenfauna. Arch Hydrobiol. 33: 388-400.

MCLaCHLAN A.J. 1977: Some effect of tube shape on the feeding of Chironomus plumosus L. (Diptera: Chironomidae). J. Anim. Ecol. 46: 139-146.

MCLACHLAN A.J. 1983: Life-history tactics of rain pool dwellers. J. Anim. Ecol. 52: 545-561.

MCLACHLAN A.J. 1986: Sexual dimorphism in midges: strategies for flight in the rain pool dwellers Chironomus imicola (Diptera: Chironomidae). J. Anim. Ecol. 55: 261-267.

MCLACHLAN A.J. 1988: Refugia and habitat partitioning among midges (Diptera: Chironomidae) in rain pools. Ecol. Entomol. 13: $185-193$.

MCLACHLAN A.J. 1989: Animal population at extreme densities: size dimorphism by frequency dependent selection in ephemeral habitats. Funct. Ecol. 3: 633-643.

McLachlan A.J. \& Cantrell M.A. 1976: Sediment development and its influence on the distribution and tube structure of Chironomus plumosus L. (Chironomidae: Diptera) in new impoundment. Freshw. Biol. 6: 437-443.

MCLACHLAN A. \& LADLE R. 2001: Life in the puddle: behavioral and life-cycle adaptations in the Diptera of tropical rain pools. Biol. Rev. 76: 377-388.

McLachlan A.J \& McLachlan S.M. 1976: Development of the mud habitat during the filling of two new lakes. Freshw. Biol. 6: 59-67.

McLachlan A.J. \& Yonow T. 1989: Reproductive strategies in rain-pool dwellers and the model freshwater insects. Hydrobiologia 171: 223-230.

MoRRIs D.W. 1991: On the evolutionary stability of dispersal to sink habitats. Am. Nat. 137: 907-911.
Morduchaj-Boltovskos F.D. 1961: Peculiarities of initial stages of benthos formation process in artificial lakes near Volga. Trudy Sovesch. Ichtiol. Kom. Akad. Nauk SSSR. 10: 123-127.

Nolte U. 1995. From egg to imago in less than seven days: Apedilum elachistius (Chironomidae). In: Cranston P.S. (ed.): Chironomids: from Genes to Ecosystems. Proc. 12th Int. Symp. on Chironomidae, Canberra, January 23-26, 1994. CSIRO Australia, East Melbourne, pp. 177-184..

OLIVIER D.R. 1971: Life history of the Chironomidae. Anmu. Rev. Entomol. 16: 211-230.

Picado C. 1913: Les bromeliaces epiphytes consideres comme milieu. Bull. Sci. Fr. Belg. 42: 215-360.

Pinder L.C.V. 1995: The habitats of chironomid larvae. In: Armitage P.D., Cranston P.S. \& Pinder L.C.V. (eds): The Chironomidae: Biology and Ecology of Non-Biting Midges. Chapman \& Hall, London, Glasgow, Weinheim, New York, Tokyo, Melbourne, Madras, pp. 107-133.

PuLliam R.H. 1988: Sources, sinks, and population regulation. Am. Nat. 132: 652-661.

Pulliam R.H. \& Danielson B.J. 1991: Source sink and habitat selection: a landscape perspectives on population dynamics. Am. Nat. Suppl. 137: 50-66.

Rossaro B. \& Delettre Y.R. 1992: Description of Smittia celtica sp.-n (Diptera, Chironomidae). Annls Soc. Entomol. Fr. 28: $365-370$.

SAETHER O.A. 1962: Larval overwintering cocoons in Endochironomus tendens Fabricius. Hydrobiologia 20: 377-381.

SuKoP I. 1974: Benthos of the fry ponds in the South Moravia. Acta Univ. Agr. A. 22: 567-572.

Steinhart M. 2000: How Chironomidae (Diptera) cope with changing water levels in a floodplain? In: Hoffrichter $\mathrm{O}$. (ed.): Late $20^{\text {th }}$ Century Research on Chironomidae: an Anthology from the $13^{\text {th }}$ International Symposium on Chironomidae. Shaker Verlag, Aachen, pp. 415-423, 543-548.

Stevens M.M., Warren G.N. \& Braysher B.D. 2003: Oviposition response of Chironomus tepperi to nitrogenous compounds and bioextracts in two-choice laboratory tests. $J$. Chem. Ecol. 29: 911-920.

StrenZKe K. 1950: Systematik, Morphologie und Ökologie der terrestrischen Chironomiden. Arch. Hydrobiol. Suppl. 18: 207-414.

Strenzke K. 1951: Die Pflanzengewässer von Scirpus silvaticus und ihre Tierwelt. Arch. Hydrobiol. 44: 123-170.

THIENEMANN A. 1921: Eine eigenartige Überwinterungsweise bei einer Chironomidenlarve. Zool. Anz. 52: 285-288.

TOKESH M. 1995: Life cycles and population dynamics. In: Armitage P.D., Cranston P.S. \& Pinder L.C.V. (eds): The Chironomidae: Biology and Ecology of Non-Biting Midges. Chapman \& Hall, London, Glasgow, Weinheim, New York, Tokyo, Melbourne, Madras, pp. 225-268

Watanabe M., Kikawada T. \& Okuda T. 2003. Increase of internal ion concentration triggers trehalose synthesis associated with cryptobiosis in larvae of Polypedilum vanderplanki. J. Exp. Biol. 206: 2281-2286.

Willassen E. \& Thunes K.H. 1996: Bracket fungi (Polyporaceae): an alternative habitat for soil chironomids (Diptera: Chironomidae). Pedobiologia 40: 405-412.

Williams D.D. 1987: The Ecology of Temporary Waters. Croom Helm, London. 193 pp.

ZAVǨEL J. 1941: Chironomidarum larvae et nymphae IV (Genus Metriocnemus v.d. Wulp.). Acta Soc. Sci. Nat. Morav. 13: $1-28$.

Received July 3, 2002; revised July 10, 2003; accepted September 4, 2003 